\begin{tabular}{|l|l|l|}
\hline \multicolumn{2}{|c|}{ PublisherInfo } \\
\hline \hline PublisherName & $:$ & BioMed Central \\
\hline \hline PublisherLocation & $:$ & London \\
\hline \hline PublisherImprintName & $:$ & BioMed Central \\
\hline \hline
\end{tabular}

\title{
Metoclopramide in the critically ill
}

\begin{tabular}{|l|l|l||}
\hline \multicolumn{2}{|c||}{ ArticleInfo } \\
\hline \hline ArticleID & $:$ & 4136 \\
\hline \hline ArticleDOI & $:$ & $10.1186 /$ ccf-1999-781 \\
\hline \hline ArticleCitationID & $:$ & 781 \\
\hline \hline ArticleSequenceNumber & $:$ & 73 \\
\hline \hline ArticleCategory & $:$ & Paper Report \\
\hline \hline ArticleFirstPage & $:$ & 1 \\
\hline \hline ArticleLastPage & $:$ & 3 \\
\hline \hline & & RegistrationDate : 1999-6-28 \\
\hline ArticleHistory & $:$ & OnlineDate \\
\hline \hline ArticleCopyright & $:$ & Current Science Ltd1999-6-28 \\
\hline \hline ArticleGrants & $:$ & \\
\hline \hline ArticleContext & $:$ & 130541111 \\
\hline \hline
\end{tabular}




\section{Keywords}

Critical illness, gastric motility, intensive Care, metoclopramide

\section{Comments}

Although only a small number of patients were studied, it is reassuring thatthe commonly used prokinetic agent on the ICU, metoclopramide, does retainits effects on gastric emptying in this population. However it is only weaksupportive evidence that the proper establishment of enteral feeding ishastened. Larger controlled studies with comparisons to other prokineticagents are still needed.

\section{Introduction}

Impairment of gastric motility is frequently encountered inthe intensive care unit (ICU) due to a multitude of factors. Although gastric emptying may beimpaired, small bowel absorptive capacity is often preserved. Early enteralfeeding to ICU patients may prevent translocation of bacteria and endotoxin,and stress ulcers, and so the promotion of gastric emptying is to be encouraged.Metoclopramide is a prokinetic agent which may be useful in this setting.

\section{Aims}

To assess whether metoclopramide improves gastric motility in thecritically ill.

\section{Methods}

Over a two day period, 10 patients receiving enteral feed on the ICUwere randomised to receive 10 mg metoclopramide IV or placebo on the firstday, followed by placebo or metoclopramide on day two. Administration of the studydrug coincided with the commencement of nasogastric feeding for a 5 hperiod, and gastric emptying was assessed on each day by measuring the areaunder the plasma 
paracetamol absorption curve at $120 \mathrm{~min}$ (AUC120) followinga $1.5 \mathrm{~g}$ bolus of paracetamol

nasogastrically. Gastric aspirates and $\mathrm{pH}$ weremeasured before administration of the study drug and at the end of the feedingperiod. Other factors that may have affected gastricemptying were controlled for during the trial period.

\section{Results}

Following metoclopramide there was a significant increase ingastric emptying when comparisons of AUC120 were made, although residualgastric aspirates did not correlate with this increase in gastric emptying.

\section{Discussion}

Interestingly those patients who were given metoclopramide onday one had greater AUC120 following saline than the other group, suggestingthat the clinical effect of metoclopramide may last longer than its knownpharmacological effect. High residual gastric aspirates do not necessarilymean absent gastric motility. In the critically ill the prokinetic effectsof intravenous metoclopramide are maintained.

\section{References}

1. Jooste CA, Mustoe J, Collee G: Metoclopramide improves gastric motility in critically ill patients. Intensive Care Med. 1999, 25: 464-468. 